\title{
Envelope Following Analysis Method of Autonomous Power Electronic Circuits
}

\author{
Toshiji Kato Member (Doshisha University, tkato@mail.doshisha.ac.jp) \\ Kaoru Inoue Member (Doshisha University, kaoinoue@mail.doshisha.ac.jp) \\ Yoshinori Kanda Non-member (Doshisha University, kanda@kairo.doshisha.ac.jp)
}

Keywords: envelope following method, autonomous circuits, circuit simulation, switch condition

Envelope following method is an efficient approximate analysis technique which considers switching dynamics. It skips analysis of several switching cycles and considers the cycles by using, for example, the trapezoidal type algorithm. It is more accurate than the averaging method and is still efficient. However it has been proposed only for nonautonomous systems.

This paper proposes a new extended envelope following method which can analyze autonomous systems which are typical in the power electronics field. The basic idea of the envelope following (EF) method is to observe a state variable vector $\boldsymbol{x}(t[k+1])=\boldsymbol{x}(t[k]+T[k])=\boldsymbol{x}[k+1]$ at a time $t=t[k+1]$ where $k$ is an integer and $T[k]$ is a switch cycle period as in Fig. 1. According to the EF analysis, intermediate $(m-2)$ switching cycles are skipped and their effects are estimated from $\boldsymbol{x}[k], \boldsymbol{x}[k+1], \boldsymbol{x}[k+m-1]$, and $\boldsymbol{x}[k+m]$. According to the trapezoidal type formulas, the following equations are derived.

$$
\begin{aligned}
\boldsymbol{x}[k+m]= & \boldsymbol{x}[k]+\frac{m}{2}\{(\boldsymbol{x}[k+1]-\boldsymbol{x}[k]) \\
& +(\boldsymbol{x}[k+m]-\boldsymbol{x}[k+m-1])\} \\
t[k+m]= & t[k]+\frac{m}{2}\{(t[k]-t[k+1]) \\
& +(t[k+m]-t[k+m-1])\} \cdots
\end{aligned}
$$

The above is a set of nonlinear equations of one unknown vector $\boldsymbol{x}[k+m-1]$ and $\boldsymbol{x}[m]$ is calculated by one-cycle integration from $\boldsymbol{x}[k+m-1]$. It can handle an autonomous system by solving the following switch condition $S_{c}(\boldsymbol{x})$ simultaneously.

$$
\begin{aligned}
S_{c}(\boldsymbol{x}[k+m-1])= & \alpha\left(v_{C}[k+m-1]-V_{\text {ref }}\right) \\
& +\beta i_{C}[k+m-1]+\Delta_{\text {hys }}=0
\end{aligned}
$$

As an application example, the previous autonomous buck converter in Fig. 2 is adopted. Computed results by the brute continuous transient and the proposed methods are shown in Fig. 3. There are little differences between the two. However the CPU time by the proposed method is a little less than a half by the conventional brute method.

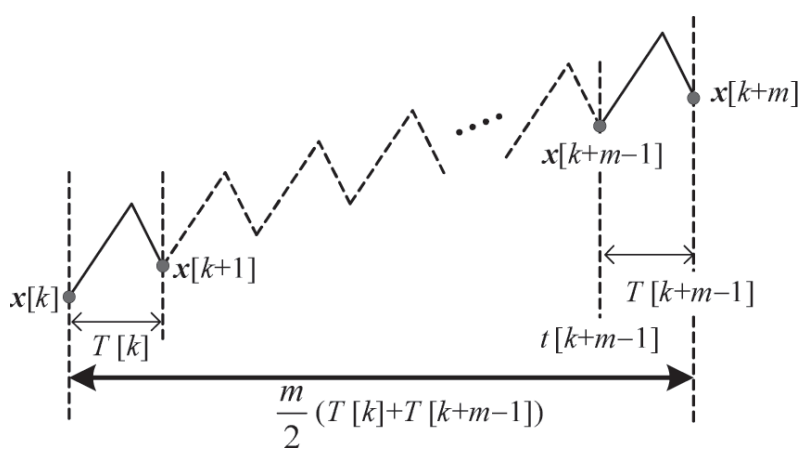

Fig. 1. Autonomous envelope following method

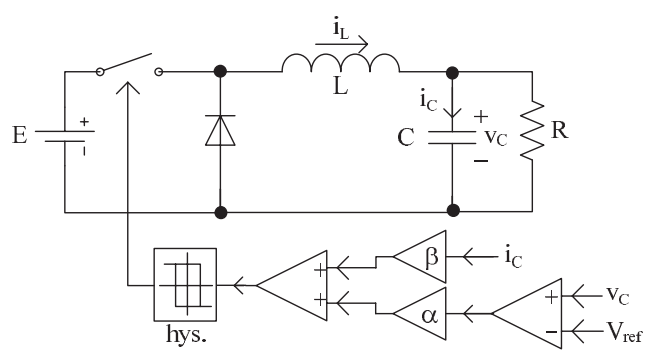

Fig. 2. Sliding-mode controlled buck converter

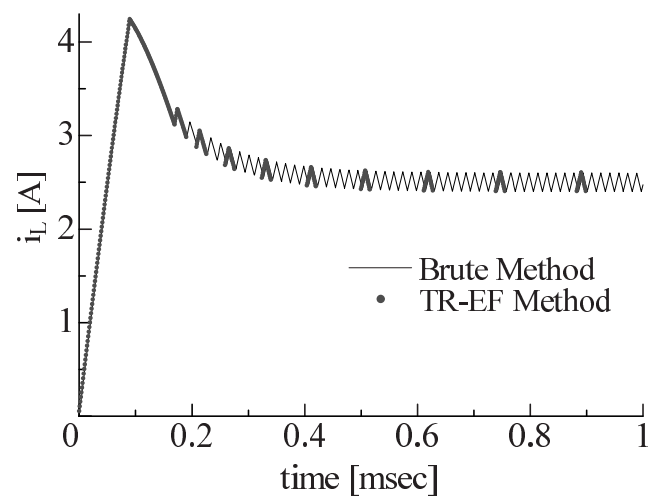

Fig. 3. Computed result of the buck converter by the brute transient and the proposed analysis 


\title{
自律系パワーエレクトロニクス回路の包絡追跡解析法
}

\author{
正 員 加藤 利次* 正 員 井上 馨* \\ 非会員 神田 義教*
}

Envelope Following Analysis Method of Autonomous Power Electronic Circuits

Toshiji Kato*, Member, Kaoru Inoue*, Member, Yoshinori Kanda*, Non-member

\begin{abstract}
The envelope following(EF) method is an approximate transient simulation technique which considers switching dynamics. It skips analysis of several switching cycles and considers the cycles by using, for example, the backward Euler or the trapezoidal type algorithm. It is more accurate than the averaging method because it considers switching ripples and it is still efficient. However it has been proposed only for nonautonomous systems. This paper proposes a new extended EF method which can also analyze autonomous systems which are typical in the power electronics field. It is extended by introducing a switching condition to the original one and the two conditions are solved simultaneously. In the numerical process, a Jacobian matrix is evaluated where switch timing sensitivities are considered. A hysteresis controlled buck and a Cuk converter examples are investigated and validated.
\end{abstract}

キーワード：包絡追跡法, 自律系回路, 回路シミュレーション, スイッチ条件

Keywords: envelope following method, autonomous circuits, circuit simulation, switch condition

\section{1. はじめに}

パワーエレクトロニクス $(\mathrm{PE})$ システムの過渡解析は, そ の設計開発において動作確認等のためよく用いられる。そ のため高効率なシミュレーション法の開発が望まれ，すで にいくつかが提案されている(1)。このうち状態平均化法は $\mathrm{PE}$ 回路をスイッチングのない回路に近似して解くため高 速であるが，スイッチングに起因するリップル等を表現で きず精度が問題となる場合が多々ある。

これに対して包絡追跡 $(\mathrm{EF})$ 法は, スイッチングを考慮 しつつも計算するスイッチ周期のジャンプ (スキップ) によ る省略化により高効率化しているため, 計算速度と精度間 でバランス可能で有用な手法である ${ }^{(2) \sim(4)}$ 。しかしながら 同法は, 従来ではその原理上, 非自律系すなわちスイッチ 周期がクロック等によりあらかじめ定められた回路にしか 適用できない欠点があった。そのため例えばヒステリシス 制御されたコンバータ等によく見られる自律系回路は解析 できなかった。

本論文は EF 法を自律系にも適用可能なように拡張した 方法を提案することを目的とする。そのためにまずはじめ

\footnotetext{
$*$ 同志社大学 工学部 電気工学科

干 610-0321 京田辺市多々羅都谷 1-3

Dept. of Electrical Engineering, Doshisha University

Kyotanabe, Kyoto, 610-0321
}

に従来の非自律系の $\mathrm{EF}$ 法の基本原理である状態変数間の $\mathrm{EF}$ 条件式についてふれる。その後, これを自律系 PE 回 路に適用可能なように拡張する。そのために同回路の特徵 であるスイッチ周期の状態依存性をスイッチ条件式により

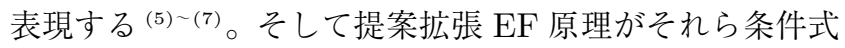
の連立に帰着することを示す。

次に提案 $\mathrm{EF}$ 法の 2 条件原理式を数值計算するための具 体的方法を説明する。まず 2 条件式は一般的に非線形で, それらは Newton-Raphson(N-R) 法での線形化により反復 修正して解く。この過程において，ヤコビアンすなわち状 態変数に関する $\mathrm{EF}$ 条件式の感度行列を計算する必要があ る (5) (9)。同行列は動作点が変わると特にスイッチ時点の変 化の影響を受けやすく，そのためその計算に対してスイッ チ時点を考慮する方法について示し, 反復計算過程の収束 性の改善を図る。

また計算時間と精度のバランス上, 過渡解析の計算時に おいて, EF 法によるスイッチ周期のジャンプ数をいかに とるかが問題となる。これに対してはすでに与えられた䛊 差指標に基づいてジャンプ数を決定する方法について提案 されている ${ }^{(4)}$ 。同様の方法を提案手法に適用してジャンプ 数を制御する方法について示す。

最後に提案原理を自律系の PE 回路へ適用する。まずス ライディングモード制御降圧形コンバータ(6)(7) の例を示 す。次に自走電流モード制御形Ć́uk コンバータ (10) の例を 
示し，両者の解析結果について吟味する。また提案原理の 適用により，従来の過渡解析法より計算時間が短縮できる ことを示す。

\section{2. 自律系回路の包絡追跡 $(\mathrm{EF})$ 法}

$\langle 2 \cdot 1\rangle \mathrm{EF}$ 法の基本原理 一般的に，パワーエレク トロニクス $(\mathrm{PE})$ 回路におけるインダクタ電流やキャパ シタ電圧等の状態変数の波形はリップルとなっていても, その包絡線はゆっくりと変化する場合が多い。これを前 提として，図 1 に示すようにスイッチ周期単位での状態 変数ベクトル $\boldsymbol{x}[k]$ の変化を考える。そのために整数 $k$ を 用いて $T[k]$ を時刻 $t=t[k]$ よりの 1 スイッチ周期と し,さらにこのスイッチ周期ごとの状態変数べクトルを $\boldsymbol{x}(t[k+1])=\boldsymbol{x}(t[k]+T[k])=\boldsymbol{x}[k+1]$ と表現するも のとする。1 スイッチ周期の両端值 $\boldsymbol{x}[k]$ および $\boldsymbol{x}[k+1]$ と $m-2$ 周期ジャンプ先の $\boldsymbol{x}[k+m-1]$ および $\boldsymbol{x}[k+m]$ の間 に次の包絡追跡 $(\mathrm{EF})$ 条件が近似的に成立するものとする。

$$
\begin{aligned}
\boldsymbol{x}[k+m]= & \boldsymbol{x}[k]+m\{(1-\theta)(\boldsymbol{x}[k+1]-\boldsymbol{x}[k]) \\
& +\theta(\boldsymbol{x}[k+m]-\boldsymbol{x}[k+m-1])\} \cdots
\end{aligned}
$$

すなわち上式において包絡線がゆっくりと変化するなら ば途中の周期を省略しても近似的に過渡変化がとらえられ る。また上式において $\theta=1$ のとき，後退オイラー形の $\mathrm{EF}$ 法 $(\mathrm{BE}-\mathrm{EF})$ となり, ダンピング効果があるものの安定性 にすぐれたアルゴリズムとなる。また $\theta=\frac{1}{2}$ のとき， ジャ ンプ元とジャンプ先の変化の平均を考慮して精度にすぐれ た台形則形の EF 法 (TR-EF) アルゴリズムとなる。

もし対象回路が非自律系であれば $T[k]=T$ なる定数と なる。そのとき時刻 $t[k]$ は次式となる。

$$
t[k]=k T
$$

このときは， $\boldsymbol{x}[k]$ および $\boldsymbol{x}[k+1]$ が既知であれば， $\boldsymbol{x}[k+m-1]$ に関して解くことができ，これが従来の EF 法 の数值計算原理となる。上の (1) 式は, 数值的には NewtonRaphson(N-R) 法による線形化により解かれる。

$$
\begin{aligned}
\boldsymbol{F} \triangleq & (1-m \theta) \boldsymbol{x}[k+m]+m \theta \boldsymbol{x}[k+m-1] \\
& -\{1-m(1-\theta)\} \boldsymbol{x}[k]-m(1-\theta) \boldsymbol{x}[k+1]=\mathbf{0}
\end{aligned}
$$

$$
\begin{aligned}
& {\left[m \theta \boldsymbol{I}+(1-m \theta) \frac{\partial \boldsymbol{x}[k+m]^{(j)}}{\partial \boldsymbol{x}[k+m-1]^{(j)}}\right]} \\
& \Delta \boldsymbol{x}[k+m-1]^{(j+1)}=-\boldsymbol{F}\left(\boldsymbol{x}^{(j)}\right) \cdots \cdots \cdots \\
& \begin{aligned}
\boldsymbol{x}[k+m-1]^{(j+1)} & =\boldsymbol{x}[k+m-1]^{(j)} \\
& +\Delta \boldsymbol{x}[k+m-1]^{(j+1)} \ldots
\end{aligned}
\end{aligned}
$$

添え字 ${ }^{(j)}$ は N-R 法の反復回数の数であり，誤差べクト ル $\Delta \boldsymbol{x}[k+m-1]^{(j+1)}$ ノルムが十分小さくなるまで繰り返

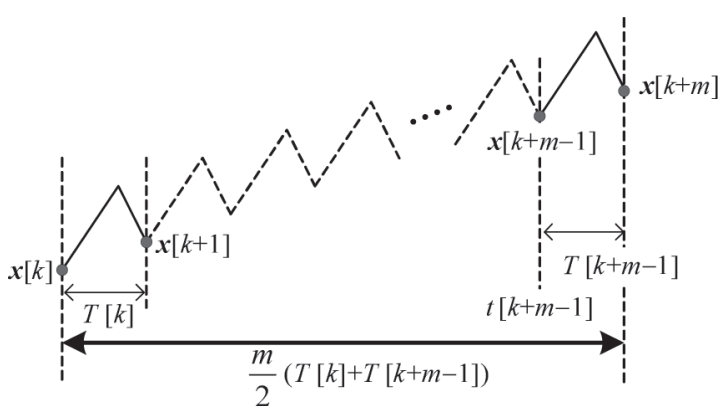

図 $1 \mathrm{EF}$ 法の原理

Fig. 1. Principle of the original envelope following method.

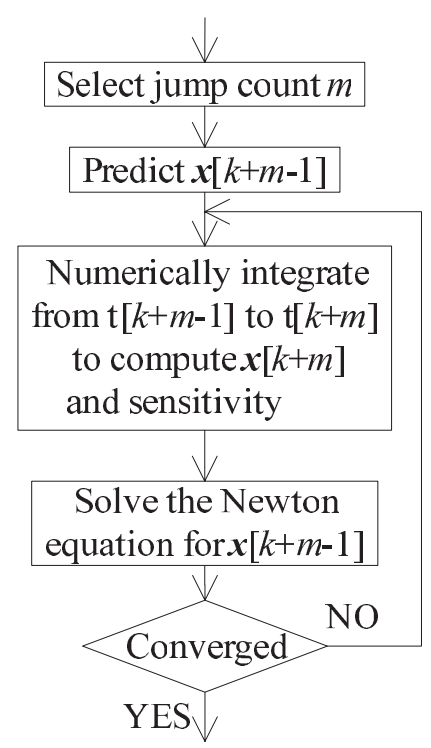

図 $2 \mathrm{EF}$ 法のアルゴリズム

Fig. 2. Algorithm of the envelope following method.

される。 $\frac{\partial \boldsymbol{x}[k+m]^{(j)}}{\partial \boldsymbol{x}[k+m-1]^{(j)}}$ は $t=t[k+m-1]$ における状態変 数の初期值 $\boldsymbol{x}[k+m-1]$ が変化したときの $t=t[k+m]$ で の状態変数 $\boldsymbol{x}[k+m]$ の変化の割合を示す感度行列である。 また，以上の $\mathrm{EF}$ 法のアルゴリズムを図 2 にフローチャー トで示す。

$\langle 2 \cdot 2\rangle$ 自律系回路に適用可能な拡張 $\mathbf{E F}$ 法 自律系 ではスイッチ周期が動作状態に依存して可変であるため $\mathrm{EF}$ 条件のみではジャンプ先における時刻 $t=t[k+m-1]$ が定 まらない。逆にこの時刻を定める条件を与えてやれば $\mathrm{EF}$ 法を自律系回路に適用可能ものに拡張してやることができ る。これは, スイッチング時刻であるから，これを表現す るスイッチ条件をもとに決定することができる。

図 3 に示すスライディングモード制御降圧コンバータ回 路を例に取り上げる。この回路の状態変数はインダクタ $L$ を流れるインダクタ電流 $i_{L}$ とキャパシタ $C$ にかかるキャ パシタ電圧 $v_{C}$ の 2 つであり, それらをまとめて状態変数べ クトル $\boldsymbol{x}$ とする。この回路は $\alpha\left(v_{C}-V_{\mathrm{ref}}\right)+\beta i_{C}$ の值がヒ 


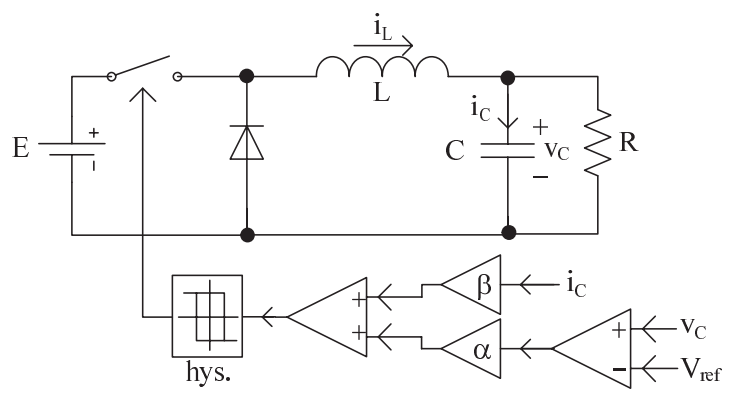

図 3 スライディングモード制御 降圧形コンバータ

Fig. 3. Sliding-mode controlled buck converter.

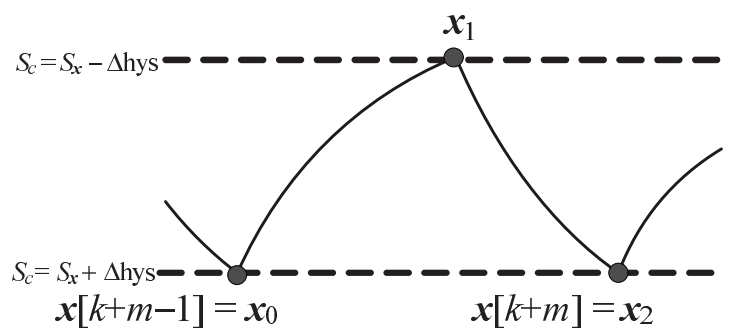

図 4 スイッチ条件関数 $S_{c}(\boldsymbol{x})$ と状態変数 $\boldsymbol{x}$ の 関係

Fig. 4. Relation between the switch condition function $S_{c}(\boldsymbol{x})$ and the state variable $\boldsymbol{x}$.

ステリシス幅 $\left(\Delta_{\text {hys }}\right)$ 内に収まるようにスイッチング制御さ れる。そのためスイッチ条件は，眓 4 に示すように，ヒス テリシスの下限でのオフからオンの条件と上限でのオンか らオフへのオフ条件の 2 種類がある。時刻 $t=t[k+m-1]$ におけるスイッチ条件 $S_{c}(\boldsymbol{x})$ は今の場合は以下となる。

$$
\begin{aligned}
S_{c}(\boldsymbol{x}[k+m-1])= & \alpha\left(v_{C}[k+m-1]-V_{\mathrm{ref}}\right) \\
& +\beta i_{C}[k+m-1]+\Delta_{\mathrm{hys}} \\
\equiv & S_{\boldsymbol{x}}+\Delta_{\mathrm{hys}}=0 \ldots \ldots
\end{aligned}
$$

ただし $S_{\boldsymbol{x}}$ は $S_{c}$ のうち $\boldsymbol{x}$ に依存する部分を示す。これ を一般化し， $\boldsymbol{x}[k+m-1]$ 付近で N-R 法により線形化すれ ば次式となる。

$$
\begin{aligned}
& \frac{\partial S_{c}(\boldsymbol{x}[k+m-1])}{\partial \boldsymbol{x}[k+m-1]} \Delta \boldsymbol{x}[k+m-1]^{(j+1)} \\
& \quad=-S_{c}\left(\boldsymbol{x}[k+m-1]^{(j)}\right) \cdots \cdots \cdots
\end{aligned}
$$

したがって, 自律系回路に適用可能な拡張 EF 法の原理 は上式と (4) 式の連立となる。ただしスイッチ条件は一つ の拘束条件を与えるため，すべてを連立すると過条件とな り, $n$ 個の状態変数を持つ系では, $(n-1)$ 個の拘束条件を 与えてやるだけでよい。そのため $(4)$ 式の任意の $(n-1)$ 個の式と上式との連立が自律系回路に適用可能な拡張 $\mathrm{EF}$ 法の原理となる。

この反復修正過程より，ジャンプ後の 1 スイッチング周 期の時間 $(t[k+m]-t[k+m-1])$ が求められるため, これ を用いて $\mathrm{EF}$ 条件式と同様に $t[k+m]$ が決定される。

$$
\begin{aligned}
t[k+m]= & t[k]+m\{(1-\theta)(t[k+1]-t[k]) \\
& +\theta(t[k+m]-t[k+m-1])\} \cdots \cdots
\end{aligned}
$$

\section{3. 感度行列の計算法}

$\langle\mathbf{3 \cdot 1}\rangle$ 感度と遷移行列 $\mathrm{EF}$ 法において (4) 式を計算 するためには $t[k+m-1]$ よりの 1 スイッチ周期間におけ る終端值 $\boldsymbol{x}[k+m]$ の始端值 $\boldsymbol{x}[k+m-1]$ に関する感度行 列を求める必要がある。この計算法に関して前述の回路例 により説明する。この回路は図 5 のように 1 スイッチング 周期中に 2 つのスイッチモードが存在する。そのモード境 界の状態変数值はそれぞれ順に $\boldsymbol{x}_{0}, \boldsymbol{x}_{1}, \boldsymbol{x}_{2}$ とし, 2 つのス イッチモード区間における遷移行列を $\phi_{1}$ と $\phi_{2}$, 電源に基 づくベクトル $\psi_{1}$ として各区間間の状態变数間の関係は以 下となる。

$$
\begin{aligned}
& \boldsymbol{x}_{1}=\phi_{1} \boldsymbol{x}_{0}+\boldsymbol{\psi}_{1} \\
& \boldsymbol{x}_{2}=\phi_{2} \boldsymbol{x}_{1} \ldots
\end{aligned}
$$

もし 2 つのモードの区間長が状態変数に依存せず一定な らば，従来考えられていたように感度行列值は 2 つの遷移 行列の単純な掛け算になるが，この例では，それら区間長 は初期值 $\boldsymbol{x}_{0}$ に依存したスイッチ時点の変動に伴って変化 するため，そうはならない。

$$
\frac{\partial \boldsymbol{x}_{2}}{\partial \boldsymbol{x}_{0}} \neq \boldsymbol{\phi}_{2} \boldsymbol{\phi}_{1}
$$

〈3・2〉 スイッチ時点の変動を考慮した感度計算法 感 度計算においては, 回路の動作状態依存したスイッチ時点 の変動を考慮して計算する必要がある。この影響を詳しく 示すと図 5 となる。ただし図において，1 スイッチ周期の時 間を $T$ ，スイッチモード区間 1,2 の時間すなわち区間長を $t_{1}, t_{2}$ としている。初期值 $\boldsymbol{x}_{0}$ が $\Delta \boldsymbol{x}_{0}$ だけ変化した際には, $\boldsymbol{x}_{1}$ の変化分 $\Delta \boldsymbol{x}_{1}$ は 2 つのモードの区間長が状態変数に依 存せず一定ならば図中に示すように $\phi_{1} \Delta x_{0}$ となり, 同様 に $\Delta \boldsymbol{x}_{2}$ は $\phi_{2} \Delta \boldsymbol{x}_{1}$ となった。今の場合, 2 つの区間の終端 でいずれもそれぞれのスイッチ条件を満足するように区間 長が変化する。そのため $t_{1}$ の終端が $\frac{\partial t_{1}}{\partial \boldsymbol{x}_{0}} \Delta \boldsymbol{x}_{0}$ だけ，また $t_{2}$ の終端が $\frac{\partial t_{2}}{\partial \boldsymbol{x}_{1}} \Delta \boldsymbol{x}_{1}$ だけ変化する。このスイッチ時点の変 化は，例えばスイッチ時点の前の区間長を減少させると次 の区間長を増加させ，もしくはその逆である。そのため例 えば, $\Delta \boldsymbol{x}_{1}$ はそのスイッチ時点の状態值 $\boldsymbol{x}_{1}$ の左側微分を $\dot{\boldsymbol{x}}_{1}^{-}$, 右側微分を $\dot{\boldsymbol{x}}_{1}^{+}$として, $\left(\dot{\boldsymbol{x}}_{1}^{-}-\dot{\boldsymbol{x}}_{1}^{+}\right) \frac{\partial t_{1}}{\partial \boldsymbol{x}_{0}} \Delta \boldsymbol{x}_{0}$ となる。 同様に $\Delta x_{2}$ を求められるが， $x_{2}$ はスイッチ周期の右端点 なので右側微分值を考慮する必要がないため, $\dot{\boldsymbol{x}}_{1}^{-} \frac{\partial t_{2}}{\partial \boldsymbol{x}_{1}} \Delta \boldsymbol{x}_{1}$ となる。以上より, 対象回路での感度は次式となる。

$$
\frac{\partial \boldsymbol{x}_{2}}{\partial \boldsymbol{x}_{0}}=\left(\dot{\boldsymbol{x}}_{2}^{-} \frac{\partial t_{2}}{\partial \boldsymbol{x}_{1}}+\boldsymbol{\phi}_{2}\right)\left(\left(\dot{\boldsymbol{x}}_{1}^{-}-\dot{\boldsymbol{x}}_{1}^{+}\right) \frac{\partial t_{1}}{\partial \boldsymbol{x}_{0}}+\phi_{1}\right)
$$

一般的に $N_{S}$ 個のスイッチ区間がある場合は次式となる。

$$
\frac{\partial \boldsymbol{x}_{N_{S}}}{\partial \boldsymbol{x}_{0}}=\prod_{i=1}^{N_{S}}\left(\dot{\boldsymbol{x}}_{i} \frac{\partial t_{i}}{\partial \boldsymbol{x}_{i-1}}+\boldsymbol{\phi}_{i}\right)
$$




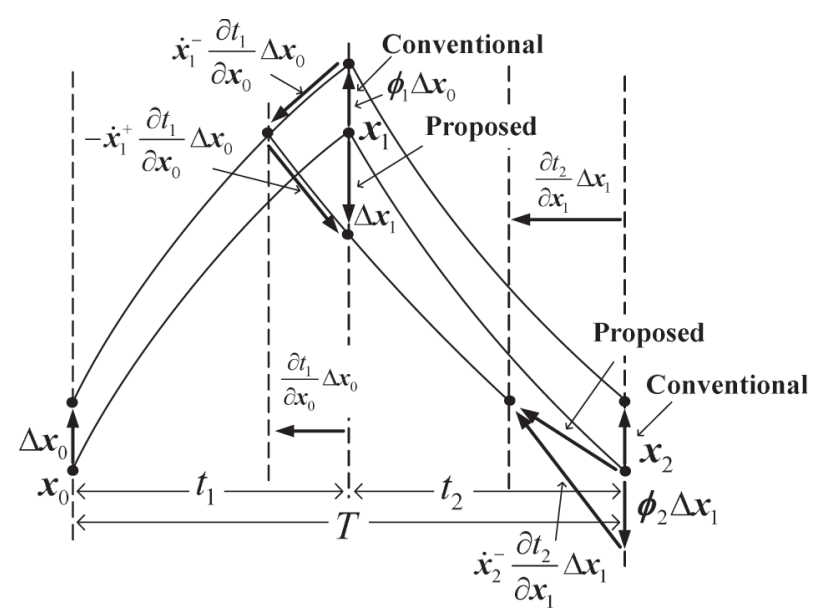

図 5 初期值の変化による状態变数の变化

Fig. 5. Change of the state variable due to the change of the initial value.

ただし

$$
\dot{\boldsymbol{x}}_{i}= \begin{cases}\dot{\boldsymbol{x}}_{i}^{-}-\dot{\boldsymbol{x}}_{i}^{+} & i \neq N_{S} \\ \dot{\boldsymbol{x}}_{i}^{-} & i=N_{S}\end{cases}
$$

$\langle 3 \cdot 3\rangle$ スイッチ時点の感度上式のスイッチ時点の状 態変化に関する感度 $\frac{\partial t_{i}}{\partial \boldsymbol{x}_{i-1}}$ は次のスイッチ条件を線形化し た式から求められる。

$$
\boldsymbol{c}_{i}^{t} \boldsymbol{x}_{i}=d_{i} \quad\left(i=1, \cdots, N_{S}\right)
$$

ここで, $c_{i}$ は係数べクトル, ${ }^{t}$ は転置行列の記号, $d_{i}$ は 定数あるいは時間の関数である。

この両辺を $\boldsymbol{x}_{i-1}$ で偏微分して, スイッチ時点の状態変 化に関する感度は以下となる。

$$
\begin{aligned}
\boldsymbol{c}_{i}^{t} \frac{\partial \boldsymbol{x}_{i}}{\partial \boldsymbol{x}_{i-1}} & =\boldsymbol{c}_{i}^{t}\left(\phi_{i}+\dot{\boldsymbol{x}}_{i}^{-} \frac{\partial t_{i}}{\partial \boldsymbol{x}_{i-1}}\right) \\
& =\dot{d}_{i} \frac{\partial t_{i}}{\partial \boldsymbol{x}_{i-1}} \ldots \ldots \ldots \ldots
\end{aligned}
$$

右辺の偏微分值は次式となる。

$$
\frac{\partial t_{i}}{\partial \boldsymbol{x}_{i-1}}=\left\{\begin{array}{cc}
\frac{\boldsymbol{c}_{i}^{t} \boldsymbol{\phi}_{i}}{\dot{d}_{i}-\boldsymbol{c}_{i}^{t} \dot{\boldsymbol{x}}_{i}^{-}} & \text {(if variable) } \\
0 & \text { (if fixed) }
\end{array}\right.
$$

以上の感度計算においては, 計算ステップがスイッチ時 点にあうように調整する必要があり，スイッチ条件を解い て設定している。また, 感度行列の計算は回路の過渡解析 と並行して行っている。

\section{4. ジャンプ数の可変制御}

$\langle\mathbf{4} \cdot \mathbf{1}\rangle$ 近似による誤差評価式 $\quad \mathrm{EF}$ 条件式 (1)のジヤ ンプ数 $m$ は大きくすると計算が速くなるが精度が落ち, 逆 に小さくすると計算が遅くなるが精度が向上する。そのた め $m$ の值は必要な精度内で最大のものが選定できるのが望 ましい。そのため誤差評価により $m$ の可変制御を行う。

誤差評価はジャンプ後の状態变数值を近似的に予測する
ことにより行う。そのためにまず各スイッチ周期ごとの関 係式を求める。スイッチ周期の始点より 1 周期間の状態遷 移行列および入力による遷移值をそれぞれ $M, q$ とすると ジャンプ先の終点は (18) 式のようになる。

$$
\begin{aligned}
& \boldsymbol{x}[k+1]=\boldsymbol{M}[k] \cdot \boldsymbol{x}[k]+\boldsymbol{q}[k] \\
& \boldsymbol{x}[k+m]=\boldsymbol{M}[k+m-1] \cdot \boldsymbol{x}[k+m-1]+\boldsymbol{q}[k+m-1]
\end{aligned}
$$

ここで $\mathrm{EF}$ 法の前提である「 $m$ 周期はなれたスイッチ波 形の状態遷移はわずかの差を除いてほぼ同じ」より, 状態遷 移関係をジャンプ先のものをジャンプ元のもので近似する。

$$
\boldsymbol{x}[k+m] \simeq \boldsymbol{M}[k] \cdot \boldsymbol{x}[k+m-1]+\boldsymbol{q}[k]
$$

ジャンプ先の予測值 $\boldsymbol{x}^{p}[k+m-1]$ は, $\mathrm{EF}$ 法の基本式 (1) 式に (19) 式を代入し整理して次式とする。

$$
\begin{gathered}
\boldsymbol{x}^{p}[k+m-1]=[m \theta \boldsymbol{I}-(m \theta-1) \boldsymbol{M}[k]]^{-1} \\
{[\{1-m(1-\theta)\} \boldsymbol{x}[k]+m(1-\theta) \boldsymbol{x}[k+1]} \\
\quad+(m \theta-1) \boldsymbol{q}[k]] \ldots \ldots \ldots \ldots \ldots \ldots . . . .
\end{gathered}
$$

$\langle\mathbf{4} \cdot \mathbf{2}\rangle$ 打切り誤差の評価 $\mathrm{EF}$ 法の基本式 (1) に含ま れるジャンプ数 $m$ を誤差評価して可変制御する。そのため にまず 1 スイッチ周期分の打切り誤差を次式で定義する ${ }^{(4)}$ 。

$$
\left|\boldsymbol{x}^{p}[k+m]-\boldsymbol{M}[k] \boldsymbol{x}^{p}[k+m-1]-\boldsymbol{q}[k]\right| \cdots \cdots
$$

これより $(21)$ 式を $m$ 周期ジャンプすなわち途中の $(m-2)$ 周期をスキップした場合の誤差 $E_{m}$ を次式で評価し $m$ の 制御を行う。

$$
\begin{aligned}
E_{m}= & \mid \boldsymbol{x}^{p}[k+m]-\boldsymbol{M}[k+1] \boldsymbol{x}^{p}[k+m-1] \\
& -\boldsymbol{q}[k+1] \mid(m-2) \ldots \ldots \ldots \ldots \ldots
\end{aligned}
$$

$m$ の值はジャンプの際に, $(20)$ 式による $\boldsymbol{x}^{p}[k+m-1]$ と $\boldsymbol{x}^{p}[k+m]$ を $(22)$ 式に代入した関係式を解いて求めら れる。そのため提案原理において $m$ を可変刻みにしてもの その計算フローは図 2 のものと同一である。

〈4・3〉 スライディングモード制御降圧形コンバータ

自律系回路の解析の例として, まずはじめに図 3 に示す自 律系の降圧コンバー夕を解析した。ここで回路パラメータは $E=10 \mathrm{~V}, V_{\text {ref }}=5 \mathrm{~V}, R=2 \Omega, L=200 \mu \mathrm{H}, C=100 \mu \mathrm{F}$, $\alpha=\beta=1$, ヒステリシスバンド幅を 0.1 , スキップ間許容誤 差 $\varepsilon=0.01$ としている。計算結果は通常の過渡計算 (Brute Method) と提案した台形則形の EF 法 (TR-EF Method) を比較して，インダクタ電流とキャパシタ電圧の計算結果 を図 6 に示すが, 両者の結果はほぼ一致している。また提案 手法により計算されたスイッチ周期波形より, 波形が定常 に近づくにつれジャンプ数が徐々に増加していることがわ かる。また，通常の過渡計算と提案 EF 法 (Proposed EF) の CPU 時間の比率を通常の過渡計算を基準として表 1 に 示すが，提案手法は通常のものの約半分に短縮できている。 


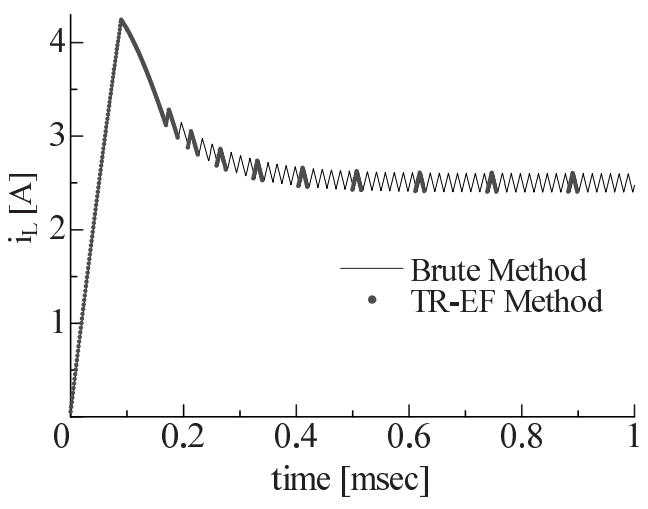

(a) Inductor current

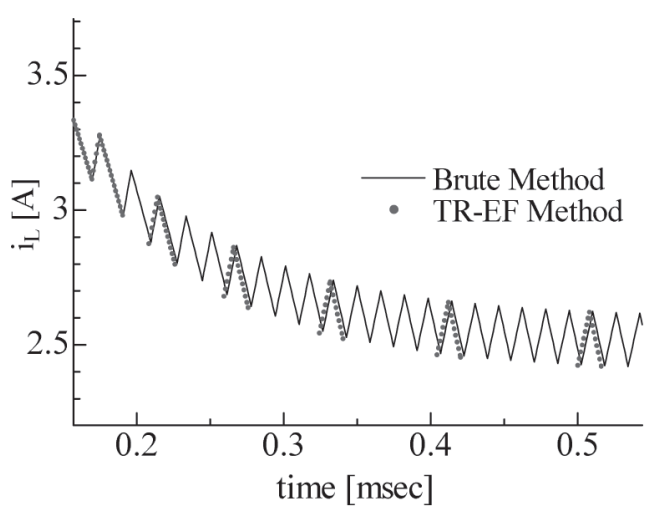

(b) Enlarged inductor current

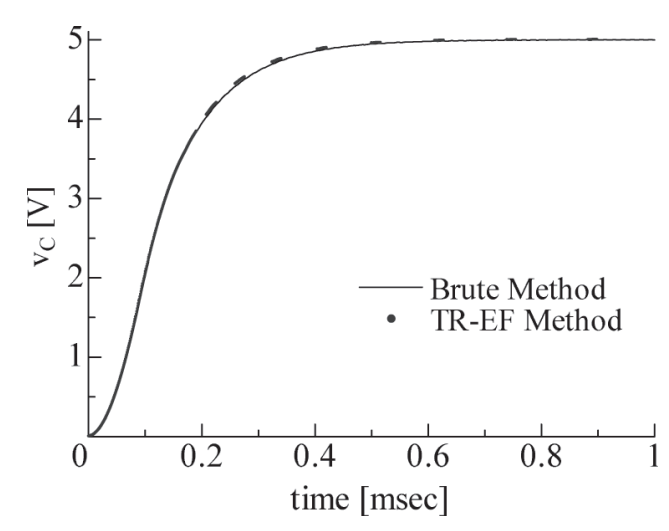

(c) Capacitor voltage

図 6 スライディングモード制御降圧形コンバー 夕計算結果

Fig. 6. Computed result of the buck converter by the brute transient and the proposed analysis.

〈4・4〉自走電流モード制御形Ćuk コンバータ＼cjkstart自律系 回路のもう一つの例として，図 7 に示す自走電流モード制御 形Ćuk コンバータを解析した。回路パラメータは $E=15 \mathrm{~V}$, $R=40 \Omega, L_{1}=L_{2}=10 \mathrm{mH}, C_{1}=C_{2}=47 \mu \mathrm{F}$, $\alpha=0.025, \beta=0.375$, ヒステリシスバンド幅を 0.01 , ス キップ間許容誤差 $\varepsilon=0.001$ とした。通常の過渡計算と提

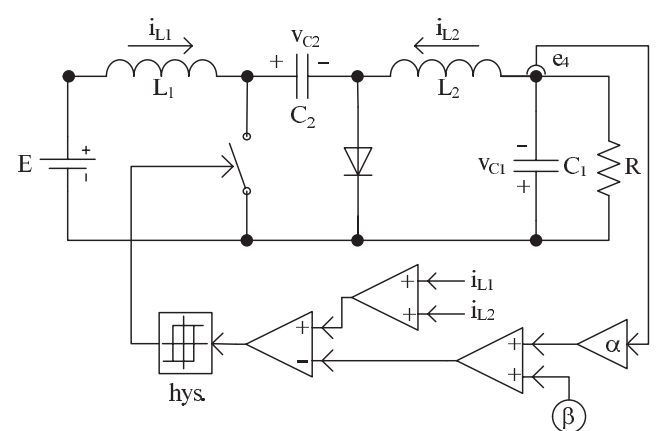

図 7 自走電流モード制御形Ćuk コンバータ

Fig. 7. Free-running current-mode-controlled Ćuk converter.

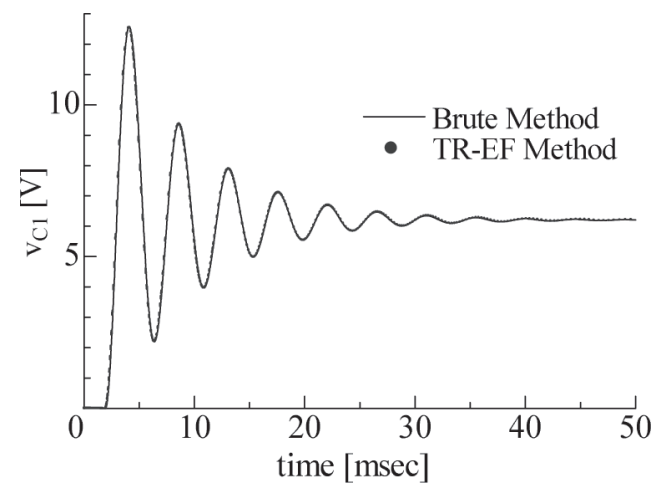

(a) Capacitor voltage

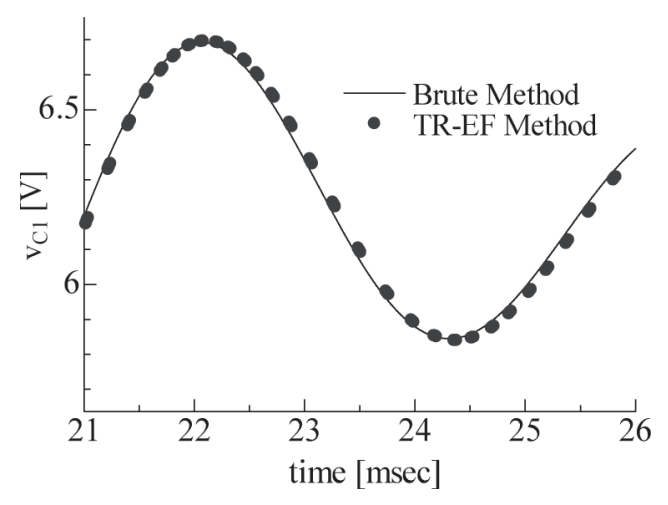

(b) Enlarged capacitor voltage

図 8 Ćukコンバー夕計算結果

Fig. 8. Computed result of the Ćuk converter by the brute transient and the proposed analysis.

\section{表 $1 \mathrm{CPU}$ 時間比}

Table 1. CPU time ratios.

\begin{tabular}{|c||c|c|}
\hline CPU time ratio & Buck & Ćuk \\
\hline \hline Brute Method & 1.000 & 1.000 \\
\hline Proposed EF & 0.493 & 0.495 \\
\hline
\end{tabular}

案 $\mathrm{EF}$ 法による計算結果を $C_{1}$ のキャパシタ電圧に関して, 図 8(a)に示すが，両者はほぼ重なっている。これを拡大し 
たものを図 8(b)に示すが, 若干の時間的遅れが見られ，こ れは EF 法による計算スイッチ周期の近似誤差の累積を示 している。またこの図はこの時間遅れを除いた波形そのも のの誤差は小さいことも示している。また計算時間を前例 と同様に示すが, この場合も提案手法は通常のものの約半 分に短縮できている。

\section{5. まとめ}

本論文は，従来では非自律系に限定されていた従来の $\mathrm{EF}$ 法を自律系のパワーエレクトロニクス回路にも拡張可能と した新しい方法を提案したものである。

(1) その拡張法は, 従来の $\mathrm{EF}$ 条件式に加えてスイッチ 条件を導入し，両者を連立して解くものである。

(2) その N-R 法に反復修正過程に拈いて，ヤコビアンす なわち感度行列を計算する必要があるが, これに動作状態 に依存したスイッチ時点の変動を考慮してより正確な感度 值が求められる。

（3）EF 法による計算過程においてスイッチ周期のジャ ンプ数を可変制御により計算をより効率化できる。 提案手法の自律系パワーエレクトロニクス回路への適用例 として，降圧形拈よびĆuk コンバータの解析を行ったが, 両者とも従来のものに近い計算精度で，数スイッチ周期程 度のジャンプ数で計算時間を約半分に短縮でき，提案手法 が対象システムのダイナミクスが速い現象と遅い現象より 成り立つマルチレートな場合に有用であることを示すこと ができた。ただしこの有用性は, 設定許容誤差と対象シス テムのマルチレート性に依存し, 数周期程度以上のジャン プ数が確保できた場合に限られ，ジャンプ数の増大に相関 して有用性が増していくことなる。

(平成 19 年 2 月 26 日受付，平成 19 年 5 月 25 日再受付)

\section{文献}

（1）パワーエレクトロニクスシステムのシミュレーション技術協同研究 委員会：「パワーエレクトロニクスシステムのシミュレーション技 術」, 電気学会技術報告 第 761 号, (2000)

(2) J. White and S.B. Leeb: "An Envelope-Following Approach to Switching Power Converter Simulation", IEEE Trans. Power Elect., Vol.6, No.2, pp.303-307, (1991)

(3) T. Kato: "Multi-rate Analysis of Power Electronic Circuits by the Envelope-Following Method with Sensitivities of Switch Timings", PESC Record, Taipei, pp.1277-1281, (1994)

(4) A. Brambilla and P. Maffezzoni: "Envelope Following Method for the Transient Analysis of Electrical Circuits", IEEE Trans. Circuits Syst. I, Vol.47, No.7, pp.999-1008, (2000)

(5) T. Kato, K. Inoue, and Y. Kanda: "Envelop Following Analysis of an Autonomous Power Electronic System", The 10th IEEE COMPEL Workshop, No.3-1, (2006)
(6) T. Kato and W. Tachibana: "Periodic Steady-State Analysis of an Autonomous Power Electronic System by a Modified Shooting Method", IEEE Trans. Power Elect., Vol.13, No.3, pp.522-527, (1998)

(7) T. Kato and W. Tachibana: "Periodic Steady-State Analysis Method of Power Electronic Circuits with Sensitivities of General Switch Timings", T.IEE Japan, Vol.118-D, No.6, pp.701-706, (1998-6) (in Japanese)

加藤利次 - 橘 和:「電力変換回路のスイッチ時点の感度を一般的に考 慮した周期定常解析法」, 電学論 D, 118, 6, pp.701-706, (1998-6)

(8) T.N. Trick, F.R. Colon, and S.P. Fan: "Computation of Capacitor Voltage and Inductor Current Sensitivities with Respect to Initial Conditions for the Steady-State Analysis of Nonlinear Periodic Circuits", IEEE Trans. Circuits Syst., Vol.CAS-22, No.5, pp.391-396, (1975)

(9) T.J. Aprille and Jr., T.N. Trick: "Steady-State Analysis of Nonlinear Circuits with Periodic Inputs", Proc. IEEE, Vol.60, pp.108-114, (1972)

(10) S. Banerjee and G.C. Verghese: "Nonlinear Phenomena in Power Electronics", Chapter 5.6 by C.K. Tse, IEEE Press, (2001)

加 藤 利 次 (正員) 1979 年 3 月同志社大学工学部電子工学

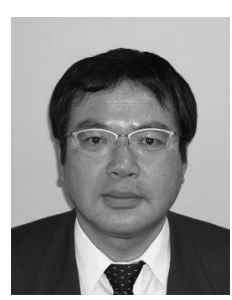
科卒業。1981 年 3 月同大学大学院博士課程前期 電気工学専攻修了。同年 4 月助手。1986 年 3 月 工学博士。同年 4 月講師。1 989 年 4 月助教授。 1998 年 4 月教授。1990 年 4 月～ 8 月 IREQ 客 員研究員。同年 9 月 1992 年 3 月 MIT LEES 客員研究員。現在，パワーエレクトロニクスシス テムのモデリングとシミュレーションをはじめ各 種回路システム解析法の開発に従事。IEEE, CIGRE などの会員。

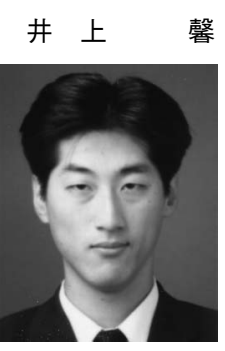

(正員) 2001 年大阪大学大学院基礎工学研究科博 士後期課程修了。日本学術振興団特別研究員 PD を経て，2001 年 10 月同志社大学工学部電気工学 科助手, 2004 年講師, 現在に至る。回転機に生 じる非線形現象の解析や時変システムの安定性に ついての研究に従事。大阪大学博士 (工学)。1999 年度システム制御情報学会賞奨励賞受賞。電子情 報通信学会, IEEE などの会員。

神 田 義 教 (非会員) 2005 年 3 月 同志社大学工学部電気工

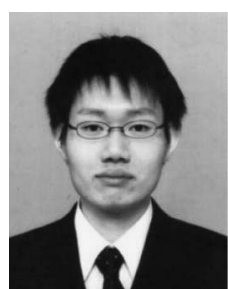
学科卒業。 2007 年 3 月 同大学院工学研究科電気 工学専攻博士課程（前期課程）修了予定。現在, 愛知時計電機（株）勤務。電力変換回路の解析に 関する研究に従事。 